\title{
Działalność firmy księgarsko-wydawniczej Ludwika Fiszera na rzecz oświaty i szkolnictwa w Łodzi w latach 1882-1932
}

Początki ruchu wydawniczego w Łodzi sięgają lat 60. XIX w. i wiążą się - jak wiele dziedzin ówczesnego życia łodzian - z rozwojem przemysłu włókienniczego'. W tym okresie drukowano tu wyłącznie publikacje niemieckie i rosyjskie, przeznaczone na użytek instytucji i przedsiębiorstw przemysłowo-handlowych (druki urzędowe, statuty, sprawozdania, regulaminy fabryczne, katalogi wyrobów, instrukcje obsługi, księgi handlowe) oraz druki użytkowe, takie jak: afisze, ogłoszenia i zaproszenia, czyli wydawnictwa określane mianem dokumentów życia społecznego ${ }^{2}$. Pierwsze druki dla potrzeb Łodzi powielano w drukarniach Warszawy, Lipska i Drezna, z czasem ich realizację przejęły firmy lokalne ${ }^{3}$.

* Dr, Uniwersytet Łódzki, Wydział Nauk o Wychowaniu, Katedra Pedagogiki Przedszkolnej i Wczesnoszkolnej, 91-408 Łódź, ul. Pomorska 46/48.

1 J. Sowiński, Polskie drukarstwo, Wrocław-Warszawa-Kraków-Gdańsk-Łódź 1988, s. 139-141.

2 Według bibliografii łódzkiej produkcji wydawniczej, do $1918 \mathrm{r}$. wydawnictwa te stanowiły największą grupę druków - 700 pozycji (45\%). Drugie pod względem liczebności były wydawnictwa naukowe i popularne - 492 (22\%), trzecie miejsce zajęły wydawnictwa religijne - 149 (15\%), kolejne: podręczniki szkolne - 131 (13\%) i ostatnią: kalendarze - 50 (5\%). Por. J. Jaworska, Bibliografia łódzkiej produkcji wydawniczej (do 1918 r.), Łódź 1975, s. 14; J. Strzałkowski, Drukarnie i księgarnie w Łodzi do 1944 roku, Łódź 1994, s. 26-28.

3 Wśród nich priorytetowe miejsce, od 1860 r., zajęła drukarnia J. Petersilgego. Zob. J. Jaworska, Zakłady drukarsko-litograficzne J. Petersilgego w Łodzi (1860-1915), „Roczniki Biblioteczne” 1972, z. 1-2, s. 521-532. 
Po upływie dwu następnych dekad łódzkie drukarstwo nabrało pewnego tempa, ciągłości i stabilizacji ${ }^{4}$. Wydawnictwa przeznaczone dla szerszych odbiorców, jak: kalendarze, podręczniki szkolne, książki oraz broszury popularne, naukowe i beletrystyczne, na łódzkim rynku wydawniczym zaczęły funkcjonować dzięki staraniom zawodowych wydawców, głównie księgarzy ${ }^{5}$. W roku 1898, który według ustaleń Janiny Jaworskiej był dla łódzkiego księgarstwa omawianego okresu rokiem najkorzystniejszym, działało jednocześnie 20 większych i mniejszych księgarni, a 5 z nich zaliczano do rzędu księgarni nakładowych ${ }^{6}$.

U progu XX w. księgarstwo w Łodzi przeżywało kryzys, wiele cenionych firm sprzedano lub zlikwidowano ${ }^{7}$. Nowe firmy księgarskie pojawiły się $w$ mieście w pierwszych latach kolejnego stulecia, ale poza nielicznymi - z powodu dużej konkurencji ze strony księgarń warszawskich - działały krótko ${ }^{8}$.

Łódzcy właściciele pierwszych księgarń lokowali je przy głównej arterii miasta - ulicy Piotrkowskiej (stanowiącej centrum handlowe), w okolicach Nowego Rynku (obecnie: Plac Wolności) i ul. Dzielnej (obecnie: Narutowicza) oraz przy ul. Nowomiejskiej i Cegielnianej (obecnie: Więckowskiego). Wśród tychże instytucji, największą i najlepiej zorganizowaną była księgarnia należąca do Ludwika Fiszera (Fischera) ${ }^{9}$.

${ }^{4}$ Liczba drukarni systematycznie wzrastała i w 1881 r. było w Łodzi 9 zakładów graficznych, w 1892 r. - 15, a na pocz. XX w. działały 23 zakłady graficzno-litograficzne i 10 małych drukarni.

${ }^{5}$ Najstarszą łódzką księgarnię założył w 1848 r. J. Gutstadt, a następnie J. Arndt i G. Berlach. Były to wyłącznie księgarnie sortymentowe. W 1872 r. księgarnię w Łodzi założył Cezar Richter, który, obok sprzedaży książek, rozpoczął w 1879 r. działalność wydawniczą. Zob. J. Jaworska, Ruch wydawniczy, [w:] Łódź. Dzieje miasta, t. I: Do 1918 r., red. B. Baranowski, J. Fijałek, Warszawa-Łódź 1980 , s. 555

6 J. Jaworska, Początki księgarstwa w Łodzi, „Roczniki Biblioteczne” 1969, nr 13, s. 132.

7 Tamże, s. 134

${ }^{8}$ Aby ratować swój byt, obok skromnego sortymentu, księgarnie prowadziły sprzedaż materiałów biurowych, artykułów szkolnych, zabawek, galanterii i wyrobów tytoniowych, przekształcając się stopniowo w sklepy z artykułami codziennej potrzeby, pozostając „księgarniami” wyłącznie z nazwy. Jeden z ówczesnych publicystów tak opisywał łódzkie księgarstwo: „Księgarnie wiodą żywot dość suchotniczy, pośredniczą w prenumerowaniu czasopism, sprzedają podręczniki szkolne, [...] zasobniejsi kupcy starają się mieć na składzie wszystkie „nowości”, zwłaszcza powieściowe, bo te największym jeszcze cieszą się powodzeniem. Któż w Łodzi na serio zajmuje się filozofią? Na kogo czekają różne dzieła historyczne, językoznawcze, krytyczno-literackie?” Zob. S. Gorski, Łódź spółczesna. Obrazki i szkice publicystyczne, Łódź 1904, s. 69-70. Zob. też: S. M., Jak powstał i co zdziałał nasz związek, „Jednodniówka. Księgarz Polski, Łódź 1-go września 1909 roku”, s. 2-4.

9 J. Jaworska, Początki księgarstwa..., s. 123, 128; taż, Zakłady drukarsko-litograficzne..., s. 528-529. W końcu XIX w. działało w Łodzi 5 księgarni nakładowych, które wydały łącznie 90 woluminów książek i broszur, z czego niemal połowa (48\%) przypadała na firmę L. Fiszera, $25 \%$ wynosił nakład księgarni C. Richtera, 18\% - L. Zonera, 5\% - R. Schatke i 4\% - K. Kolińskiej). 


\section{Właściciele firmy}

Prawnym właścicielem księgarni i wydawnictwa przy ul. Piotrowskiej 17 w Łodzi Ludwik Fiszer ${ }^{10}$ został w kwietniu 1882 r. ${ }^{11}$ Miał 38 lat i był żonaty z siedemnastoletnią wówczas Melanią Henriettą z domu Miks. Księgarnię odkupił od Cezarego Richtera, który, jako księgarz „pierwszy w Łodzi spróbował swych sił na polu wydawniczym"12. Po dwóch latach L. Fiszer przeniósł księgarnię do innego lokalu, mieszczącego się przy ul. Zawadzkiej 1 (dziś: Próchnika), natomiast w 1896 r. - ponownie na ul. Piotrkowską, do obszernego lokum, tym razem pod numerem $48^{13}$.

Sukcesy na polu wydawniczym i rozwój działalności sortymentowej, ale przede wszystkim względy ekonomiczne były przyczyną powołania do życia, w 1898 r., filii łódzkiej księgarni, którą L. Fiszer umieścił w Warszawie, początkowo przy ul. Długiej 20, a następnie przy ul. Bielańskiej $9^{14}$. Oddział ten spełniał funkcję przedstawicielstwa łódzkiej centrali, prowadził sprzedaż hurtową wydawnictw łódzkich, realizował zamówienia na wydawnictwa warszawskie i przyjmował dostawy z zagranicy. Warto nadmienić, że wszelkie przesyłki zagraniczne dla wszystkich księgarń Królestwa Polskiego kierowano bezpośrednio do Warszawy, gdzie podlegały najpierw odprawie celnej (obsługiwała ją firma spedycyjna), a potem kontroli cenzorskiej przy ul. Miodowej (Warszawskij Komitiet po Diełam Inostrannoj Pie(czati) ${ }^{15}$. Rewizja odbywała się w obecności przedstawiciela odbiorcy ${ }^{16}$.

10 Ludwik Fiszer (12 II 1844-15 XII 1900) urodził się w Łodzi, pochodził z rodziny, która przybyła do miasta z alzackiego Strasburga. Ukończył w Łodzi czteroklasową szkołę Niemiecko-Rosyjską, następnie wyjechał do Warszawy i rozpoczął praktykę księgarską w dobrze prosperującej firmie Michała Glücksberga. W tym czasie ukończył też szkołę wieczorową i kursy buchalteryjne. Po czterech latach został czeladnikiem - pomocnikiem księgarskim. Wrócił do Łodzi i rozpoczął pracę, najpierw w sklepie z tytoniem, a następnie jako księgarz i właściciel firmy księgarsko-wydawniczej. Z żoną Melanią miał 6 dzieci: Melanię Emilię, Emilię Huldę, Ludwika Adama, Stefanię Frydę, Alicję Janinę i Kazimierza Oskara. Większość członków rodziny zatrudniona była w firmie. Zob. Słownik pracowników książki polskiej, hasło „Ludwik Fiszer” - opr. J. Jaworska, Warszawa-Łódź 1972, s. 225-226; J. Strzałkowski, Drukarnie i księgarnie..., s. 50; J. Krakowiak, Od Fiszera do „Pegaza”, Łódź 2005, s. 8.

11 L. Fiszer, Wspomnienia starego księgarza, Warszawa 1959, s. 5; J. Strzałkowski, Drukarnie i księgarnie..., s. 50; J. Krakowiak, Od Fiszera..., s. 7-8.

12 J. Jaworska, Początki księgarstwa..., s. 120.

13 Führer durch Lodz, Łódź 1893, s. 42; Führer durch Lodz, Łódź 1898, s. 42; Słownik pracowników..., s. 225;

14 J. Strzałkowski, Drukarnie i księgarnie...; Słownik pracowników...; J. Krakowiak, Od Fiszera..., s. 8. Syn Ludwika Fiszera - Ludwik Fiszer (junior), jako czas powstania filii warszawskiej podaje rok 1895. Por. L. Fiszer, Wspomnienia..., s. 15.

15 L. Fiszer, Wspomnienia..., s. 13; J. Kostecki, Publikacje importowane na rynku księgarskim zaboru rosyjskiego w latach 1865-1904. Z problemów geografii kontaktów, [w:] Książka i prasa w systemie komunikacji społecznej. Przeszłość, dzień dzisiejszy, perspektywy, red. M. Juda, Lublin 2002, s. 51-57. Warszawski Komitet Cenzury powołano w 1869 r., współpracował z inspektorami nadzoru drukarń, litografii, księgarni i zakładów pomocniczych. Zob. J. Sowiński, Polskie..., s. 116.

${ }_{16}$ Na przełomie XIX/XX w., po zakończeniu rządów warszawskiego generał-gubernatora Hurki, nastąpiło złagodzenie sytuacji politycznej w Królestwie Polskim. Z tego względu, ale również z powodu wzrastającej liczby łódzkich wydawnictw recenzowanych w Warszawie, w połowie 1897 r. władze carskie przydzieliły Łodzi oddzielnego cenzora. Zob. J. Jaworska, Cenzura carska $w$ Łodzi przed pierwszą wojną światową, „Roczniki Biblioteczne” 1973, z. 1/2, s. 121-156. Warto również nadmienić, 
Jednak inicjatywy L. Fiszera w zakresie popularyzacji książki nie trwały długo, zmarł 5 grudnia 1900 r., po osiemnastu zaledwie latach działalności.

Od dnia 10 lipca 1900 r. łódzką firmę księgarsko-wydawniczą „Ludwik Fiszer" prowadziła wdowa Melania Fiszer, natomiast kierownictwo na kolejne dwie dekady (do 1920 r.) objął w firmie długoletni pracownik księgarni i zarazem brat właścicielki - Paweł Miks (Mix) ${ }^{17}$. Rozwijał dotychczasową działalność instytucji, zwłaszcza w wymiarze edytorskim. Według J. Jaworskiej, księgarnia L. Fiszera - wprawdzie największa w Łodzi - za życia założyciela funkcjonowała bez podbudowy naukowo-bibliograficznej i bez „wielkomiejskiego rozmachu”, zaś pod kierunkiem P. Miksa znalazła się w gronie najbardziej liczących się firm księgarskich w Królestwie Polskim ${ }^{18}$. W 1906 r. zatrudniano 22 pracowników (9 osób zajmowało się ekspedycją frontową). Dbano również o własną łódzką wypożyczalnię książek, w 1910 r. było w niej 10 tys. woluminów.

Filię warszawską M. Fiszer zlikwidowała w 1911 r., gdyż syn Fiszerów - Ludwik Adam Fiszer (junior) ${ }^{19}$, po odbyciu praktyki księgarskiej (w księgarni rodzinnej oraz za granicą) nabył w Warszawie księgarnię pod nazwą: „E. Wende i Sp." Odsprzedał wówczas rodzinie swoje udziały w firmie ojca i przeniósł się do Warszawy.

Warto w tym miejscu przytoczyć wspomnienia jednego z księgarzy, odbywającego czteroletnią praktykę w łódzkiej księgarni Fiszerów - Henryka Nikodemskiego. Tak charakteryzował on atmosferę w miejscu pracy i kontakty z M. Fiszerową: „Panowały tam iście patriarchalne zwyczaje, przypominające żywcem stosunki w firmie Mincla z Lalki Prusa. Każdego bowiem popołudnia zajeżdżał przed księgarnię powóz, w którym pani Fiszerowa, wdowa po Ludwiku i główna właścicielka, przywoziła dla wszystkich pracowników podwieczorek, wzorem p. Minclowej. Na święta Bożego Narodzenia każdy z pracowników otrzymywał gratyfikację w wysokości jednomiesięcznej pensji plus wartościową książkę w oprawie, w okresie zaś wzmożonego ruchu, przed rozpoczęciem roku szkolnego, pensja była podwójna. Ponadto weszło już w stały zwyczaj, że w porze jesiennej obdarzano każdego pracownika $50 \mathrm{~kg}$ owoców pochodzących z ogrodów firmy. W pierwszych latach

że do 1905 r., w związku z cenzurą, księgarnie zobowiązano do prowadzenia ksiąg inwentarzowych z wykazem posiadanych pozycji książkowych. Inspektor łódzkich księgarni - Lisiewicz, jak wspominał L. Fiszer jr, „przychodził do księgarni codziennie, szperał po półkach i sprawdzał, czy każda książka ma swój numer, który sprawdzał z książką inwentarzową. [...] Nie wierzył, żebyśmy nie sprzedawali książek zabronionych. Pomimo to jednak nie udało mu się nigdy wykryć cokolwiek bądź nielegalnego. Był to na ogół porządny człowiek i na szczęście bibliofil. Bardzo go interesowały dobrze wydane książki i starodruki, które mu podsuwano w czasie rewizji”. Zob. L. Fiszer, Wspomnienia..., s. 24.

17 Archiwum Państwowe w Łodzi (APŁ), Archiwum Włodzimierza Pfeiffera (AWP), s. a. 1: Sprawy księgarskie 1916-1935, k. 179; Czterdziestolecie, „Przegląd Księgarski” 1923, nr 4, s. 44.

18 J. Jaworska, Początki księgarstwa..., s. 125.

19 Ludwik Adam Fiszer (1890-1962) od 1906 r. odbywał praktykę w firmie ojca Ludwika Fiszera. W latach 1909-1910 przebywał na praktyce księgarskiej w Lipsku, Paryżu i Londynie. We wrześniu 1909 r., z inicjatywy grona łódzkich księgarzy wydał jednodniówkę pt. „Księgarz Polski”, nawołując do założenia pisma o profilu księgarskim, które, pod redakcją A. Heflicha, powstało rok później. Zob. „Jednodniówka. Księgarz Polski, Łódź 1-go września 1909 roku” (na stronie 24 napis: Nakładem i staraniem księgarni Ludwika Fiszera w Łodzi); L. Fiszer, Wspomnienia..., s. 23; M. Mlekicka, Wydawcy książek w Warszawie w okresie zaborów, Warszawa 1987, s. 193. 
po I wojnie światowej gratyfikację świąteczną uzupełniano jeszcze kuponem z czystej wełny na garnitur"20.

W 1918 r. spadkobiercy L. Fiszera zmienili adres firmy po raz ostatni, lokując księgarnię i wypożyczalnię książek przy ul. Piotrkowskiej 47, we własnym domu rodzinnym ${ }^{21}$. Główny skład hurtowy mieścił się przy ul. Zielonej 2 i Południowej 26, w specjalnie wybudowanych magazynach.

Od lutego 1921 r., po śmierci matki, rodzinną księgarnią zarządzał najmłodszy syn L. Fiszera - Kazimierz Oskar Fiszer ${ }^{22}$, firmę prowadził pod tą samą nazwą. Zanim jednak objął w niej przewodnictwo, udał się do brata Ludwika do Warszawy, oświadczając mu - jak ten wspominał, „[...] że posiada za mało wiedzy fachowej, ażeby samodzielnie prowadzić księgarnię łódzką, i pragnąłby poznać w księgarni Wendego chociażby elementarne zasady prowadzenia przedsiębiorstwa. Początkowo pracował u mnie w charakterze kierownika wydziału hurtowego, a po kilkunastu miesiącach zrobiłem go swoim zastępcą - i na tym stanowisku pozostał w Warszawie przez cały 1919 rok"23.

Umiejętności praktyczne K. Fiszera pozwoliły mu, z dużym powodzeniem, kontynuować dzieło rodziców. Przez dalsze 11 lat księgarnia Fiszerów należała do najpopularniejszych w mieście. Kazimierz rozwijał działalność wydawniczą, a wiele przedsięwzięć podejmował w kooperacji z warszawską firmą brata Ludwika.

\section{Działalność oświatowa księgarni w latach 1882-1914}

Już samo pomieszczenie frontowe księgarni przy ul. Piotrkowskiej 48 (a następnie 47), o dwu wielkich oknach wystawowych, informowało łódzką społeczność o świetnym zaopatrzeniu. L. Fiszer prowadził dobrze dobrany sortyment książek polskich i obcojęzycznych (w tym również podręczniki), posiadał dział nut, skład artykułów szkolnych i materiałów biurowych, prowadził prenumeratę pism, introligatornię, założył również wypożyczalnię książek w kilku językach: polskim, niemieckim, rosyjskim, francuskim i angielskim, starając się kształtować potrzeby czytelnicze ówczesnego, wielonarodowego społeczeństwa Łodzi ${ }^{24}$. Nakładem

20 S. Dippel, O księgarzach, którzy przeminęli, Wrocław-Warszawa-Kraków-Gdańsk 1976, s. 25. „Z okazji ukończenia wojny”, w 1918 r., firma L. Fiszera przekazała swoim pracownikom 10 tys. marek. Pieniądze złożono w Kasie Przezorności i Pomocy Warszawskich Pracowników Księgarskich. Zob. Kronika. Piękny czyn, „Księgarz” 1919, nr 1, s. 8.

21 J. Krakowiak, Od Fiszera..., s. 13.

22 Kazimierz Oskar Fiszer (1895-1943) po ukończeniu gimnazjum, w latach 1916-1918 przebywał na emigracji w Rosji. W 1922 r. otworzył też księgarnię w Katowicach, przy ul. Poprzecznej 1, jako „samodzielny oddział księgarni łódzkiej”, po 4 latach założył drugą księgarnię w tym mieście (ul. Rynek 2). W 1928 r. obydwa punkty przeniósł do nowego lokum przy ul. Poprzecznej 2. Zob. APŁ, AWP, s. a. 1: Sprawy księgarskie..., k. 108; J. Krakowiak, Od Fiszera..., s. 11; M. Mlekicka, Wydawcy książek...

${ }^{23}$ L. Fiszer, Wspomnienia..., s. 206.

24 J. Strzałkowski, Drukarnie i księgarnie... W 1897 r. struktura narodowościowa Łodzi była następująca: Polacy (145,6 tys. - 46,4\%), Niemcy (67,3 tys. - 21,4\%), Żydzi (92,4 tys. - 29,4\%), Rosjanie (7,4 tys. - 2,4\%), inni (1,3 tys. - 0,4\%). W 1915 r.: Polacy - 51,4\%, Niemcy - 11,5\%, Żydzi - 36,4\%, inni (w tym Rosjanie) - 0,7\%. Por. J. K. Janczak, Ludność, [w:] Łódź. Dzieje miasta..., s. 218-219. 
księgarni L. Fiszera ukazywały się kalendarze, czasopisma, plany Łodzi (w 1883 i 1887 r.), zbiory pocztówek z widokami miasta oraz katalogi własnych i posiadanych w sprzedaży wydawnictw.

Równocześnie z działalnością sortymentową L. Fiszer rozpoczął działalność wydawniczą, przejmując od C. Richtera kalendarz w języku niemieckim: „Lodzer Haus- und Familien-Kalender" (publikowany do końca lat 80. XIX w.) ${ }^{25}$. W latach 1899-1900 wydawał pierwsze w Łodzi czasopismo kulturalno-literackie, tygodnik ilustrowany „Ognisko Rodzinne”26, wpisujące się w nurt wydawnictw popularnych, przeznaczonych dla niższych warstw ludności. O przyjętym profilu informował już w pierwszym numerze periodyku: „Lekarze, adwokaci, inżynierowie wydają pisma specjalistyczne dla swej sfery, lud wiejski ma swoje pisma, ludzie wykształceni mają swoje pisma bardzo duże, pisane tak, aby zrozumieć mogli, co się dzieje nowego w polityce, literaturze lub sztuce, ale poza tymi ludźmi jest, zwłaszcza w Łodzi i jej okolicach, cała masa klasy pracującej, która nie może czytywać pism innych, bo są pisane mniej przystępnie i za dużo kosztują, a rwie się całą duszą do poznania wiedzy. Dla nich to, dla tych pracujących rozpoczynamy dziś nasze wydawnictwo..."27. Pomimo jednak starannego doboru treści, estetycznej szaty graficznej i przystępnej ceny (15 kopiejek za numer), pismo wychodziło w niewielkim nakładzie (400 egzemplarzy) i przynosiło deficyt ${ }^{28}$.

Cykl wydawnictw kierowanych do młodego odbiorcy L. Fiszer zapoczątkował w 1889 r., publikując Najpiękniejsze baśnie H. Ch. Andersena. Po trzech latach zainicjował serię wydawniczą pod nazwą „Biblioteka Powszechna”, drukując dramat W. Szekspira Romeo i Julia, którego przekład przygotowała córka byłego prezydenta Łodzi - Andrzeja Rosickiego (1862-1865), Antonina Wiktoria Rosicka ${ }^{29}$. Wśród książek opublikowanych w tym czasie dla młodzieży znalazły się: Dziennik ucznia E. de Amicisa (1899), Skarb Sonory L. Bellemare'a, Syn marnotrawny i Prawda zawsze zwycięża F. Hoffmana oraz Mali Robinsoni Wielkiej Kartuzy J. Tauliera ${ }^{30}$.

${ }^{25}$ J. Jaworska, Ruch wydawniczy..., s. 557. Rocznik zawierał, obok niemiecko-rosyjskiego kalendarium, teksty o charakterze informacyjnym (porady gospodarskie, ogrodnicze, opowiadania, wiersze, powiastki obrazkowe), ukazywał się w latach 1879-1889.

${ }^{26}$ W 1899 r. w „Rozwoju” pisano: „Dzisiaj [20 III 1899 - J. S.] wyszedł pierwszy numer nowego tygodnika polskiego w Łodzi p.t. «Ognisko rodzinne». Numer przedstawia się bardzo pokaźnie: treść urozmaicona, starannie dobrana i sporo ilustracyj”. Informowano również, że „będzie to pismo popularne, prowadzone w duchu chrześcijańskim”, a redakcja "dbać będzie o zachowanie tradycyi rodzinnej, ojczystego języka i wiary przodków...” Por. „Rozwój” 1899, nr 75, s. 2.

${ }^{27}$ Cyt. za: J. Jaworska, Łódzkie wydawnictwa popularne (przed 1918 r.), „Roczniki Biblioteczne” 1971 , z. 1/2, s. 60. Według ustaleń J. Jaworskiej, wiadomości podawano w formie popularnej, ale na dobrym poziomie. Ważne miejsce zajmowała literatura piękna, proza i poezja, zamieszczano wiersze, powieści, nowele i opowiadania łódzkich literatów (A. Gliszczyńskiego, A. Mogielnickiego, A. Warty), nie pomijano także wierszy M. Konopnickiej, J. Słowackiego i A. Puszkina.

${ }_{28}$ Po 1900 r. nabywcą pisma został nauczyciel o nazwisku Thomas, redagował je „do spółki ze swoim bratem”. W 1902 r. „Ognisko Rodzinne” nabył Wiktor Czajewski - redaktor i wydawca „Rozwoju”. Zob. „Rozwój” 1905, nr 47, s. 2; 1907, nr 245, s. 3.

${ }^{29}$ H. Duninówna, Gawędy o dawnej Łodzi, Łódź 1958, s. 266; L. Fiszer, Wspomnienia..., s. 18.

30 J. Jaworska, Początki księgarstwa..., s. 124; taż, Ruch wydawniczy..., s. 556-557. 
Pomiędzy pozycjami wydawniczymi centralne miejsce w księgarni L. Fiszera zajmowały podręczniki szkolne, z których początkowo korzystał tylko rynek lokalny, z czasem jednak znalazły wielu nabywców na terenie Królestwa Polskiego i były kilkakrotnie wznawiane ${ }^{31}$. Zdaniem Janiny Krakowiak, to właśnie podręczniki szkolne, a nie literatura piękna, stały się podstawową gałęzią specjalizacyjną firmy ${ }^{32}$. W latach 1889-1900 L. Fiszer wydał prawie 40 pozycji książkowych. Nakład książek dla młodzieży wynosił 2-3 tys. egzemplarzy, natomiast podręczników - do 6 tys. ${ }^{33}$ Tłoczono je w łódzkich drukarniach: Jana Petersilge, Karoliny Kotlińskiej i „Dziennika Łódzkiego” i dostarczano w komis księgarniom podłódzkim, a także większości księgarń w Królestwie Polskim ${ }^{34}$. Kolporterami byli żydowscy furmanie, tzw. komisjonerzy, przyjeżdżający do Łodzi kilka razy w tygodniu po manufakturę z miejscowych fabryk ${ }^{35}$. Prace introligatorskie wykonywała introligatornia Hübel i Denck w Lipskư ${ }^{36}$, dokąd wysyłano wydrukowane arkusze książki oraz kolorowe ilustracje sprowadzane z Londynu.

Warto dodać, że kulminacyjny punkt swej działalności w zakresie produkcji i sprzedaży wydawnictw podręcznikowych firma Fiszerów przeżyła w latach 1905-1907, kiedy wskutek działań rewolucyjnych i strajków szkolnych doszło do liberalizacji polityki edukacyjnej caratu. Członkowie partii politycznych, związków zawodowych i organizacji społecznych wywalczyli wówczas pewne ulgi w dziedzinie oświaty, co spowodowało ożywienie życia kulturalnego i społeczno-oświatowego. Wprowadzenie języka polskiego do szkół, otwieranie nowych placówek oświatowych z możliwością nauczania w języku polskim oraz zmiany w programach szkolnych zaważyły zarówno na rozszerzeniu zakresu tematycznego podręczników, jak i na wzroście ich nakładów, stawiając jednocześnie przed łódzkim księgarstwem nowe zadania. Nakładem księgarni ukazywały się wtedy podręczniki w języku polskim do wszystkich przedmiotów, zaopatrywano w nie nie tylko szkoły łódzkie, ale także, jak już pisano, większość szkół Królestwa Polskiego, a firmę zaliczano do najpoważniejszych wydawców podręcznikowych na tym obszarze ${ }^{37}$.

Pierwsze podręczniki ukazujące się jeszcze staraniem L. Fiszera seniora nie odbiegały w swej istocie od wydawanych wtedy przez innych nakładców ${ }^{38}$. Były

31 Szkolnictwo w Łodzi rozwijało się bardzo wolno. Po 1863 r. istniało 9 szkół elementarnych rządowych, jedna 4-klasowa szkoła powiatowa realna i kilka szkół prywatnych. Po kilku latach zorganizowano siedmioklasowe gimnazjum niemieckie, kolejne szkoły prywatne i szkoły fabryczne. Zob. E. Podgórska, Szkolnictwo elementarne w Łodzi w latach 1808-1914, Łódź 1966, s. 72-118.

32 J. Krakowiak, Od Fiszera..., s. 22; L. Fiszer, Wspomnienia..., s. 10.

33 J. Jaworska, Początki księgarstwa..., s. 124-125.

34 Taż, Zakłady drukarsko-litograficzne, s. 529.

35 W. Pawlak, Na łódzkim bruku 1901-1918, Łódź 1986, s. 18.

36 Janusz Dunin wskazuje na powiązania wydawców, księgarzy i drukarzy polskich z wydawcami niemieckimi. Autor stwierdza, że wydawcy polscy u niemieckich szukali wzorów, które naśladowali; importowano technologie, czcionki, a często również papier i kliszę. Por. J. Dunin, Rozwój cech wydawniczych polskiej książki literackiej XIX-XX wieku, „Acta Universitatis Lodziensis” 1982, nr 4, s. 23.

37 J. Jaworska, Ruch wydawniczy..., s. 559.

${ }^{38}$ W 1888 r. podręcznik do języka niemieckiego napisał i wydał Karol August Hoch - nauczyciel szkoły fabrycznej Karola Scheiblera. W tym samym roku i w latach kolejnych 4 niemieckie podręczniki, autorstwa właściciela szkoły prywatnej w Łodzi - Henryka Zirklera, wydał księgarz - Robert Schatke. Zob. J. Jaworska, Łódzkie wydawnictwa podręcznikowe (do 1918 r.), „Roczniki Biblioteczne” 1970, nr 1-2, s. 329. 
to bowiem podręczniki do nauki języka niemieckiego pt. Deutsches Lesebuch mit Übungen zum Übersetzen $(1889,1890,1894)$ w opracowaniu takich autorów, jak August Kühn - nauczyciel łódzkiej szkoły elementarnej i Henryk Zirkler - właściciel szkoły prywatnej ${ }^{39}$. Po 1900 r. wydawnictwo L. Fiszera siedmiokrotnie publikowało podręcznik pt. Lehrgang der deutschen Sprache Waldemara Osterloffa, w nakładzie 2-10 tys. egzemplarzy ${ }^{40}$. Porównywalnie dużym powodzeniem cieszyły się książki Alberta Ledera: Deutsches Lesebuch für mehrklassige Schulen oraz Deutsche Grammatik (tę ostatnią w latach 1902-1917 wznawiano osiem razy). Warto nadmienić, że zaspokajano w ten sposób potrzeby miejscowej ludności niemieckiej, która stanowiła wówczas w Łodzi dość liczną grupę narodowościową.

Od 1898 r. L. Fiszer nawiązał współpracę z łódzkimi nauczycielami: Władysławem Kokowskim i Kazimierzem Kędzierskim, którzy opracowali dla niego podręczniki i elementarze przeznaczone do nauki języka polskiego. W tymże roku ukazały się dwa pierwsze podręczniki W. Kokowskiego: Krótka etymologia języka polskiego i Krótka składnia języka polskiego łącznie z zasadami użycia znaków pisarskich ${ }^{41}$. W 1900 r. opublikowano pierwszą edycję podręcznika dla szkół polskich Mój elementarz pióra K. Kędzierskiego. Wydania późniejsze tej pozycji zostały rozszerzone i - począwszy od wydania trzeciego, które ukazało się w 1905 r. - zmieniły tytuł na Elementarz i książka do czytania (wychodziły razem lub w dwóch częściach, osobno Elementarz i osobno Książka do czytania) ${ }^{42}$. Pomocniczą publikacją do nauczania podstaw czytania było Abecadło ruchome - literki służące do układania wyrazów i zdań, które wydano w 1901 r., natomiast naukę pisania wspomagał Kurs kaligrafii polskiej W. Glińskiego (1906, 1910).

Podręczniki, wznawiane przez firmę L. Fiszera przez cały okres jej działalności, stanowiły, jak już nadmieniono, bardzo poważną pozycję wydawniczą. Elementarze K. Kędzierskiego, wydawane w przeciętnym nakładzie 2 tys. egzemplarzy (wydanie pierwsze - 6,5 tys.), po pozytywnych recenzjach wydawniczych zwiększyły nakład nawet do 15 tys. ${ }^{43}$ Uzupełnieniem podręczników do szkół elementarnych były Wypisy polskie o domu i świecie, również w opracowaniu K. Kędzierskiego, które w oparciu o opowiadania i wiersze miały uczyć poprawnej pisowni i mowy, poza tym wzbogacały wiedzę dziecka o treści z dziedziny historii, geografii, przyrody i literatury (w latach 1906-1917 ukazało się siedem ich wydań w nakładzie 5-7 tys. egzemplarzy). W. Kokowski - nauczyciel łódzkiej szkoły handlowej, opracował dla klas starszych dość popularne wówczas podręczniki z gramatyki i etymologii języka polskiego, które również miały po kilka wydań:

39 W latach: 1894, 1896 L. Fiszer wydał też Erstes Lesebuch pióra H. Zirklera.

40 J. Jaworska, Łódzkie wydawnictwa..., s. 337. W. Osterloff redagował też dla firmy L. Fiszera broszurki ujęte w serie: „Biblioteka Autorów Niemieckich” oraz drugie wydanie: „Niemiecka Biblioteka Szkolna”, które pełniły pomocniczą rolę w nauczaniu języka niemieckiego. W 1909 r. księgarnia proponowała nauczycielom dwie publikacje W. Osterloffa Rady i wskazówki pedagogów dla nauczycieli szkół ludowych (w cenie 80 kopiejek) oraz Pierwsze dni w szkole (36 kopiejek). Zob. „Jednodniówka. Księgarz...," s. 27.

41 Zob. J. Krakowiak, Od Fiszera..., s. 22-23.

42 „Rozwój” 1906, nr 194, s. 12; J. Jaworska, Łódzkie wydawnictwa..., s. 331-332.

43 Do I wojny światowej ukazało się 21 wydań tego podręcznika, w 1917 r. wydano go po raz dwudziesty drugi, publikowany był również w Polsce międzywojennej. J. Jaworska, Łódzkie wydawnictwa..., s. 332. 
Krótka składnia języka polskiego (6 wydań w latach 1898-1913) i Krótka etymologia języka polskiego (11 wydań: 1898-1916), ale także Słownik ortograficzny języka polskiego (1903), Teoria literatury (1904) i Ćwiczenia gramatyczne (1905) ${ }^{44}$.

Podręczniki do nauki języka rosyjskiego publikowane były przez firmę L. Fiszera, jak i innych łódzkich wydawców w niewielkim zakresie, z uwagi na to, iż wydawano je głównie w Cesarstwie Rosyjskim. Firma wydała tylko podręcznik Prakticzeskaja russkaja gramatyka w opracowaniu J. M. Watsztejna oraz słownik rosyjsko-polski i polsko-rosyjski autorstwa J. Bohuszewicza (1913) ${ }^{45}$.

W zbiorze podręczników do nauki języków obcych w księgarni L. Fiszera znalazły się również książki francuskie. W 1906 r. firma wznowiła, wydany trzy lata wcześniej, podręcznik Antoniego Mroczka pt. Premières lectures et premières lecons de choses oraz wydała podręcznik dla szkół gimnazjalnych Rossmanna i Schmidta, przygotowany dla uczniów polskich przez Natalię Osterloff. Powodzeniem cieszyły się również słowniki: polsko-francuski i francusko-polski w opracowaniu Piotra Dahlmana, które opublikowano w 1910 r. ${ }^{46}$

Pomocniczą rolę w nauce języków obcych pełniły tzw. samouczki, które nakładem Fiszerów ukazały się pod tytułami: Polak we Francji (1906), Polak w Niemczech (1913) i Polak we Włoszech (1914).

W grupie podręczników z zakresu matematyki najczęściej spotykaną formą były tzw. zbiory zadań. Dużą popularność zdobyły wydawane przez Fiszerów polskie Zbiory zadań arytmetycznych Romualda Cieślewskiego (w latach 1906-1918 ukazało się 5 wydań w nakładzie po ok. 2 tys. egzemplarzy), Zygmunta Rządkowskiego (1905), A. Okraszewskiego (1906, 1917) i Bonifacego Wróblewskiego (1908) oraz w języku niemieckim Rechenbuch für Volks- und Elementarschulen (cz. I, II, III; 1907-1917) pióra R. Zimmermanna ${ }^{47}$. W tej dziedzinie mieściła się również Algebra elementarna Michała Feldbluma (1906, 1907), Zbiór zadań algebraicznych w zakresie programu gimnazjalnego (1907) w opracowaniu Tadeusza Jastrzębca oraz tłumaczenie Tablic logarytmicznych i trygonometrycznych (1907) autorstwa Oskara Schlömilcha ${ }^{48}$.

Wysokim poziomem edytorskim charakteryzowały się, wydane w 18991900 r., dwie pozycje z dziedziny zoologii: w opracowaniu C. H. Schuberta Historia naturalna (cz. I obejmowała Zwierzęta ssące, cz. II - Gady) i Historia naturalna ptaków ${ }^{49}$.

Skromnie natomiast przedstawiał się dorobek księgarni Fiszerów w zakresie wydawnictw przeznaczonych do nauki przyrody i geografii. Po 1905 r. wydano podręcznik do nauki przyrody pt. Kurs elementarny zoologii, botaniki, mineralogii (1906) w opracowaniu E. Skotnickiej oraz po rosyjsku - w 1893 r. podręcznik J. S. Stejngauera Pierwyje uroki geografii (do 1914 r. ukazało się kilka wydań).

\footnotetext{
44 Tamże; Ruch wydawniczy w Łodzi w ostatnich latach 10-ciu, „Rozwój” 1907, nr 245, s. 3-4; „Rozwój” 1906, nr 194, s. 12.

45 J. Jaworska, Łódzkie wydawnictwa..., s. 336.

46 Tamże, s. 338.

47 Tamże, s. 340; „Rozwój” 1906, nr 194, s. 12.

48 J. Jaworska, Łódzkie wydawnictwa..., s. 341.

49 Ruch wydawniczy w Łodzi..., „Rozwój” 1907, nr 245, s. 3-4; J. Jaworska, Początki księgarstwa..., s. 124.
} 
Po polsku wydano w 1905 r. Geografię początkową, której autor ukrył się pod pseudonimem Stanisław, rok później uczniowie szkół mogli korzystać z pozycji K. Kędzierskiego Początki geografii (4 wydania do 1917 r.), natomiast od 1907 r. - z Geografii powszechnej w opracowaniu Alfreda Fuchsa ${ }^{50}$.

Zawartość publikacji podręcznikowych z zakresu edukacji historycznej wiązała się z ówczesną sytuacją polityczną (Łódź znajdowała się w obrębie zaboru rosyjskiego). Historia Polski była w szkole przedmiotem zakazanym, natomiast podręczniki do historii powszechnej pisano pod naciskiem ostrej cenzury carskiej, toteż niewielu autorów podejmowało się tego zadania. Po 1905 r. nakładem księgarni L. Fiszera wydano Dzieje powszechne opracowane przez W. Osterloffa i Józefa Szustera, które do czasu zakończenia I wojny uzyskały 7 edycji. Już w 1914 r. ukazała się Historia Polski S. Groblińskiego, przeznaczona dla dzieci młodszych ${ }^{51}$.

Istotne miejsce w rozwijającym się ruchu popularyzatorskim zajmowała wiedza społeczno-ekonomiczna, wzbudzająca zainteresowanie robotników łódzkich, zwłaszcza wobec toczących się w latach 1905-1907 walk ekonomicznych i wyłaniających się programów społecznych. W zakresie tej problematyki, w ramach „Biblioteczki Społeczno-Ekonomicznej”, nakładem Fiszera ukazała się broszura autorstwa Karola Forstera Franklin jako przykład oszczędzania, Sheridan jak przykład marnotrawstwa $(1911)^{52}$.

O głównym profilu działalności firmy Fiszerów i przewadze wydawnictw podręcznikowych, beletrystycznych oraz dla młodzieży, figurujących w jej ofercie, świadczyć może opis codziennej pracy w księgarni, zwłaszcza w tzw. sezonie szkolnym i świątecznym, kiedy to następował okres nasilonej sprzedaży tychże publikacji. „Począwszy od 1 września - pisał we wspomnieniach L. Fiszer junior - wygląd wewnętrzny księgarni ulegał zasadniczej zmianie. Z kontuarów usuwane były wszystkie książki, pisma, materiały piśmienne itp. Cały personel w godzinach popołudniowych zmobilizowany był do sprzedaży frontowej książek szkolnych. Obroty przez pierwsze dwa tygodnie przekraczały dziennie 3000 rubli, a każdy pracownik w swoim bloczku kasowym miał ponad 100 pozycji. Personel pomocniczy oraz kobiety zatrudnione w księgarni bez przerwy pakowały sprzedane książki”" ${ }^{3}$. Z początkiem grudnia natomiast „[...] księgarnia przybierała odświętny wygląd. Ustawiało się stoły, na których rozkładane były wydawnictwa przeznaczone na podarunki gwiazdkowe dla dorosłych i młodzieży. Obroty w grudniu były bardzo duże, lecz nie dorównywały obrotom w sezonie szkolnym"54.

50 Ruch wydawniczy w Łodzi...; J. Jaworska, Łódzkie wydawnictwa..., s. 343.

51 J. Jaworska, Łódzkie wydawnictwa..., s. 343; W 1907 r. w „Rozwoju” księgarnia L. Fiszera polecała "następujące najnowsze utwory wybitniejszych autorów dla dzieci i młodzieży”: J. K. Kraszewskiego (Kordecki obrońca Częstochowy), W. Trąpczyńskiego (Pod Pieskową Skałą, opowiadanie osnute na tle wypadków z 1863 roku; Oblężenie Paryża - na tle wojny francusko-pruskiej; W służbie Czarnego Orła - powieść historyczna z czasów Stanisława Augusta), W. Przyborowskiego (Olszynka Grochowska - na tle wypadków z 1831 r.; Adiutant Księcia Józefa Poniatowskiego; Racławice - powieść historyczna z czasów ks. Józefa Poniatowskiego). Zob. „Rozwój” 1907, nr 251, s. 10.

52 J. Jaworska, Łódzkie wydawnictwa popularne..., s. 70.

53 L. Fiszer, Wspomnienia..., s. 12.

54 Tamże, s. 13. 


\section{Działalność księgarni na rzecz szkolnictwa i oświaty w latach 1914-1932}

Nawrót represji carskich w Łodzi przed I wojną światową zahamował działalność społeczną i oświatowo-kulturalną, co niekorzystnie rzutowało również na rynek wydawniczy. Dezorganizację życia miasta spotęgował wybuch wojny i wkroczenie do Łodzi wojsk niemieckich. Okupacja miasta trwała od grudnia 1914 do listopada 1918 roku $^{55}$. W tym okresie produkcja wydawnicza, tak jak wiele dziedzin życia społeczno-gospodarczego, zupełnie się załamała. Stagnację potęgował brak zapotrzebowania na podręczniki i pomoce szkolne, niedostatek środków produkcji nakładczej, zniszczenie zakładów drukarskich czy rekwizycja maszyn ${ }^{56}$. W stosunku do wydawnictw lokalnych administracja niemiecka wprowadziła własną cenzurę, zlikwidowano bądź zawieszono wiele pism i publikacji (głównie rosyjskich i żydowskich) ${ }^{57}$.

Jednak na przełomie lat 1916/1917 środowisko nauczycieli podjęło inicjatywy w kierunku organizacji łódzkiego szkolnictwa, zaczęto uruchamiać szkoły i kursy dokształcające, opracowywano nowe programy nauczania ${ }^{58}$. Ponownie wzrosło zapotrzebowanie na pomoce naukowe, ale przede wszystkim na podręczniki szkolne. Swoisty renesans przeżywały, wielokrotnie wznawiane, podręczniki do nauki języka polskiego w opracowaniu B. Wocalewskiego i K. Kędzierskiego.

Z wydawców zawodowych jedynie firma L. Fiszera powróciła w tym czasie do przedwojennego poziomu wydawniczego, publikując podręczniki szkolne i poradniki zawodowe ${ }^{59}$. Obok licznych wznowień ${ }^{60}$, jej nakładem ukazało się kilka

55 P. Samuś, Życie polityczno-społeczne, [w:] Łódź. Dzieje miasta..., s. 454-460, 477-479.

56 Część drukarni zlikwidowali okupanci niemieccy, inne zamykali sami właściciele z powodu braku zamówień - z jednej strony, z drugiej zaś - z powodu „głodu papierowego” oraz konfiskaty maszyn. Ze sprzętu zarekwirowanego w łódzkich drukarniach władze okupacyjne zorganizowały dla własnych celów niemiecką drukarnię państwową Deutsche Staatsdrückerei. Zob. J. Jaworska, Ruch wydawniczy..., s. 561.

57 J. Jaworska, Niemiecka cenzura prasowa w Łodzi w okresie pierwszej wojny światowej, „Roczniki Biblioteczne” 1967, z. 1/2, s. 152-163. Już 20 XII 1914 r. powstał w Łodzi Niemiecki Zarząd Prasowy. Cenzurowano książki z Niemiec i Austrii, przywóz książek z innych państw był zabroniony. W celu wywozu książek poza granicę Niemiec założono w Lipsku specjalne biuro. Publikowano też wykazy książek zabronionych; od marca 1916 r. ukazało się 14 takich wykazów (ostatni - we wrześniu 1918 r.). Wykazy obejmowały 864 tytuły. Zob. APŁ, AWP, s. a. 3: Materiały dotyczące zarządzeń cenzury w sprawie „książek zakazanych” 1916-1920, k. 1, 2, 3, 4 i in.; L. Fiszer, Wspomnienia..., s. 184-185.

58 E. Podgórska, Szkolnictwo, [w:] Łódź. Dzieje miasta..., s. 525-526.

59 Por. m.in. ogłoszenie reklamujące firmę w 1916 r. zamieszczone w czasopiśmie. „Jednodniówka na dochód wielkiej kwesty ogólnołódzkiej Ratujcie dzieci, Łódź 11 czerwca 1916 r.”, s. 34.

60 Wznowiono: w 1917 r. Elementarz (22 wydanie) i Wypisy polskie o domu i o świecie (7 wydanie) K. Kędzierskiego oraz Krótką gramatykę języka polskiego Marii Sadowskiej. W związku z zapotrzebowaniem na podręczniki szkolne do nauki języka niemieckiego w czasie I wojny, firma L. Fiszera wznowiła podręcznik H. Zirklera Erstes Lesebuch (21 nakład w 1918 r.), Deutsches Literaturkunde W. Osterloffa i Deutsche Grammatik A. Ledera. Z podręczników do nauk ścisłych ponownie wydano: Zbiór zadań arytmetycznych R. Cieślewskiego i Z. Rządkowskiego, Geografię początkową Stanisława J., Początki geografii K. Kędzierskiego oraz Dzieje powszechne W. Osterloffa i J. Szustera. Zob. J. Jaworska, Łódzkie wydawnictwa..., s. 344. 
nowych podręczników: przeznaczona dla uczestników kursów wieczorowych Nauka czytania i pisania K. Kędzierskiego, a dla uczniów klas starszych - Nauka pisowni polskiej autorstwa Stanisława Lubicz-Majewskiego (nauczyciela szkoły w Pabianicach) i Składnia języka polskiego w opracowaniu łódzkiej nauczycielki Lucyny Osieckiej. Powodzeniem cieszył się również zbiór poezji, prozy literackiej i publicystyki pt. Złote kłosy (1917) pióra Józefa Radwańskiego ${ }^{61}$. Zupełnie nowe wydania miały także podręczniki do nauki przedmiotów ścisłych, jak: Krótka geometria dla szkół miejskich pióra Romana Racięckiego, Trygonometria dla szkół średnich Alfonsa Rebière oraz Podręcznik do nauk przyrodniczych autorstwa Heleny Litauer-Oppenheimowej62.

W ramach poradnictwa zawodowego Fiszerowie wydali m.in. serię pt. „Biblioteczka Rzemieślnicza”, która obejmowała poradniki opracowane przez nauczycieli łódzkich szkół i kursów zawodowych, jak Bronisław Gustawicz, Władysław Gustawicz, Mieczysław Sroczyński i Emil Wyrobek, a także serię „Biblioteka Techniczno-Naukowa dla Wszystkich" pod redakcją Mieczysława Dominikiewicza ${ }^{63}$. Publikacje te adresowano do pracowników różnych zawodów: metalowców, ślusarzy, murarzy, cieśli, malarzy.

Warto nadmienić, że podręczniki szkolne, których edycja, zwłaszcza po 1905 r., wybitnie wzrosła, stanowiły wśród łódzkich wydawnictw w latach I wojny poważną pozycję - 13,7\% całej lokalnej produkcji. Dla porównania, w ogólnej produkcji wydawniczej Królestwa Polskiego w latach 1909-1911, podręczniki stanowiły 3-4\% ogólnej liczby wydawnictw. Ten znaczący dorobek wydawniczy, według J. Jaworskiej, miasto zawdzięcza właśnie księgarni L. Fiszera ${ }^{64}$. Na 400 podręczników wydanych w Łodzi przed 1918 r., prawie 300 wyprodukowała firma L. Fiszera ${ }^{65}$.

Z chwilą odzyskania niepodległości w 1918 r., jak wspominał L. Fiszer, „Księgarzom zdawało się, że przed księgarstwem polskim otwiera się nowa, wspaniała era. Prędko jednak nasze nadzieje prysnęły, warunki pracy w przemyśle wydawniczym stawały się coraz trudniejsze, przede wszystkim z powodu braku papieru"66. Pomimo trudności w wielu dziedzinach życia społeczno-gospodarczego, najważniejszym postulatem nowych władz miasta Łodzi w sferze oświaty i kultury stało się zorganizowanie szkolnictwa powszechnego i ograniczenie analfabetyzmu. Już w październiku 1918 r. Rada Miejska podjęła uchwałę wzywającą Magistrat do powołania, przy Wydziale Szkolnictwa, Komisji Powszechnego Nauczania, a w czerwcu kolejnego roku uchwaliła wprowadzenie obowiązku szkolnego ${ }^{67}$. Przed łódzkim księgarstwem pojawiły się nowe perspektywy ${ }^{68}$.

61 Tamże, s. 340.

62 Tamże, s. 346.

63 APŁ, AWP, s. a. 4: Księgarstwo łódzkie. Korespondencja 1937-1938; J. Jaworska, Ruch wydawniczy..., s. 561; taż, Łódzkie wydawnictwa popularne..., s. 74-75.

64 Taż, Łódzkie wydawnictwa..., s. 347.

65 Taż, Ruch wydawniczy..., s. 557.

66 L. Fiszer, Wspomnienia..., s. 212.

67 Księga pamiątkowa dziesięciolecia samorządu miasta Łodzi 1919-1929, Łódź 1930, s. 123124; „Dziennik Zarządu Miasta Łodzi” 1919, nr 2, s. 8-9.

68 W latach 1918-1923 nastąpił dwukrotny wzrost liczby łódzkich księgarni (z 34 do 68), spo- 
Po przejęciu, w 1921 r., firmy Fiszerów przez najmłodszego syna - Kazimierza Fiszera, kontynuowano dotychczasową działalność wydawniczą ${ }^{69}$. Przez kolejną dekadę księgarnia należała do najlepszych w mieście.

Swój rozwój w latach 1918-1932 firma Fiszerów zawdzięczała przede wszystkim jednemu z długoletnich pracowników księgarni - Włodzimierzowi Pfeifferowi ${ }^{70}$. W 1920 r. otrzymał on stanowisko kierownika działu sortymentowego, pięć lat później został prokurentem firmy. Powierzenie W. Pfeifferowi tak odpowiedzialnego stanowiska było wyrazem ogromnego zaufania ze strony ówczesnego właściciela firmy - K. Fiszera oraz dowodem uznania dla kompetencji, operatywności i uczciwości księgarza. Urząd ten W. Pfeiffer piastował do czasu likwidacji firmy we wrześniu 1932 r.

Przedmiotem obrotu handlowego księgarni Fiszerów w Łodzi w latach 19181932 były nadal wydawnictwa własne, książki przyjęte na skład główny oraz wydawnictwa firm, które księgarnia reprezentowała, m.in.: z Warszawy - E. Wendego i S-ki, M. Arzta, Instytutu Wydawniczego „Biblioteka Polska”, „Domu Książki Polskiej”, Gebethnera i Wolffa, „Naszej Księgarni”, Towarzystwa Wydawniczego J. Mortkowicza, Wydawnictwa Polskiego z Poznania i „Książnicy Atlas” ze Lwowa.

Księgarnia posiadała „największy wybór i największe zapasy” podręczników szkolnych dla wszystkich typów szkół, książek dla dzieci i młodzieży (zalecanych przez Ministerstwo Wyznań Religijnych i Oświecenia Publicznego), publikacji dla bibliotek szkolnych, dysponowała wydawnictwami pedagogicznymi, popularnonaukowymi, mapami geograficznymi i historycznymi, atlasami, utworami scenicznymi dla teatrów szkolnych i zespołów amatorskich, słownikami i podręcznikami do nauki języków obcych ${ }^{71}$. W swej ofercie miała też biblioteczki utworów klasycznych i lektur szkolnych, śpiewniki szkolne, polskie i obce wydawnictwa beletrystyczne i „największy w Łodzi” wybór nut. Przyjmowano zamówienia na wydawnictwa angielskie, francuskie i niemieckie oraz prenumeratę czasopism „we wszystkich językach"72.

wodowany zapotrzebowaniem na podręczniki i lektury szkolne. Jednak tylko firmy L. Fiszera oraz Gebethnera i Wolffa miały obszerne, reprezentacyjne lokale, pozostałe składały się zwykle z jednego pomieszczenia. J. Strzałkowski, Drukarnie i księgarnie..., s. 35-36; N. Kraśko, Instytucje wydawnicze w II Rzeczypospolitej, Warszawa 2001, s. 44.

69 S. Dippel, O księgarzach..., s. 25.

70 Włodzimierz Pfeiffer (1890-1941) z księgarnią L. Fiszera związany był od 1904 r. Tutaj odbył czteroletnią praktykę księgarską, a w latach 1914-1919 kierował działem nut. W 1922 r. został zaangażowany przez K. Fiszera do organizacji filii księgarni w Katowicach. Bezpośrednio po likwidacji firmy Fiszerów (kupiła ją Szarlotta Seipelt), od dnia 1 X 1932 r. objął stanowisko kierownika działu sortymentowego w „Księgarni S. Seipelt”. APŁ, AWP, s. a. 1: Sprawy księgarskie 1916-1935, k. 40-43; „Przegląd Księgarski” 1934, nr 19-20, s. 119-120; M. Budziarek, Łodzianie, Łódź 2000, s. 165-170.

${ }_{71}$ APŁ, AWP, s. a. 1: Sprawy księgarskie... Odpowiadała tym samym na zapotrzebowanie w zakresie publikacji naukowych i podręcznikowych. W 1918 r. na terenie Łodzi znajdowało się 339 różnego typu szkół. Na liczbę tę przypadały 142 szkoły miejskie powszechne, 32 szkoły powszechne prywatne, 81 chederów (jawnych), 37 ochronek i 47 szkół średnich. Wśród szkół powszechnych publicznych funkcjonowało 66 szkół polskich, 37 niemieckich, 38 żydowskich i 1 szkoła rosyjska. Narodowy charakter posiadało również szkolnictwo średnie: 24 szkoły polskie, 11 - niemieckich, 12 - żydowskich. Zob. A. Rzepkowski, Ludność miasta Łodzi w latach 1918-1939, Łódź 2008, s. 102.

72 APŁ, AWP, S. a. 1: Sprawy księgarskie... 
W 1923 r. księgarnia oferowała publikacje rodzimych autorów, m.in: S. Żeromskiego, H. Sienkiewicza, W. Reymonta, E. Orzeszkowej, S. Wyspiańskiego oraz obcych: J. Londona, J. Conrada, C. Farrere'a, A. France'a. Z czasopism dużym powodzeniem cieszyły się „Przegląd Warszawski” i „Przegląd Współczesny”73.

Warto dodać, że oferując społeczeństwu Łodzi z Katalogu nut z 1927 r. bogaty (liczący ok. 2248 partytur) zbiór druków muzycznych, firma odpowiadała na zapotrzebowanie nie tylko towarzystw i zespołów muzycznych, ale również pojedynczych wykonawców i miłośników muzyki ${ }^{74}$.

Do 1932 r. wydano wiele cennych książek dla dzieci, spośród których wspaniale prezentowały się Bajki braci Grimm, powieść Boženy Němcovej Babunia i trzy powieści Adolfa Dygasińskiego: Wielkie łowy, Beldonek oraz Przygody młodzieńca czyli Robinson polski. Rozpoczęto publikację kilku tomów „Biblioteki Przygód i Podróży", ale sytuacja finansowa firmy nie pozwoliła na ich kontynuację ${ }^{75}$.

W zakres działań firmy L. Fiszera na rzecz łódzkiej oświaty włączyć można również wypożyczalnię książek, którą pierwszy i kolejni właściciele prowadzili przez cały okres istnienia firmy ${ }^{76}$. Mieściła się w lokalu księgarni od momentu jej założenia w 1882 r. ${ }^{77}$ Kierowniczką w latach 1918-1931 była Apolonia Michalska. W tym okresie wypożyczalnia dysponowała bogatym, bo liczącym 4332 tytuły, wielojęzycznym księgozbiorem (polskim, angielskim, rosyjskim, francuskim i niemieckim), wykaz wszystkich książek umieszczony był w katalogu ${ }^{78}$. Przeważała beletrystyka, powieści, nowele, opowiadania i dramaty wydawców warszawskich, krakowskich i lwowskich, w mniejszym stopniu oferowano publikacje wydawane w Łodzi, Petersburgu, Poznaniu, Płocku, Wilnie, Kijowie, Wiedniu, Paryżu, Lublinie, Tarnowie czy Płocku ${ }^{79}$. Korzystanie z książek było odpłatne. Wypożyczalnia czynna była przez 6 dni w tygodniu. Przez cały rok 1929 z jej zbiorów skorzystało 650 czytelników.

73 J. Krakowiak, Od Fiszera..., s. 19.

74 Druki muzyczne w księgarni L. Fiszera zawierały: utwory na fortepian na dwie i na cztery ręce, na skrzypce, na skrzypce i fortepian, na wiolonczelę, utwory do śpiewu, tańca, ćwiczenia do śpiewu i na wiolonczelę.

75 J. Krakowiak, Od Fiszera..., s. 24.

76 Od lat 80. XIX w. mieszkańcy Łodzi mogli korzystać z książek oferowanych im przez wypożyczalnie istniejące przy ówczesnych księgarniach łódzkich, oprócz L. Fiszera, także C. Richtera, S. Strakuna i R. Schatke. Książki wypożyczały także pojedyncze osoby i instytucje: adwokaci, lekarze, przemysłowcy, stowarzyszenia o charakterze kulturalno-oświatowym i biblioteki szkolne. Zob. J. Konieczna, Biblioteki, [w:] Łódź. Dzieje miasta..., s. 563-564.

77 W 1910 r. w jednym z dzienników ogłaszano: „Wypożyczalnia książek w 5-ciu językach Księgarni Ludwika Fiszera przy ul. Piotrkowskiej 48 została ogromnie powiększona. Zawiera wszelkie nowości belletrystyczne w języku polskim, rosyjskim, francuskim, niemieckim i angielskim. Przeszło 10,000 tomów". Podawano też warunki wypożyczeń: abonament miesięczny na 1 książkę (z prawem jednorazowej zamiany codziennie) wynosił: kaucja 1 rubel (rb) i opłata miesięczna 0,40 rb; na 2 książki - 2 rb i 0,75 rb; na 3 książki - 2 i 1 rb; 4 książki - 3 i 1,30 rb; 6 książek - 4 i 1,60 rb. Por. „Rozwój” 1910, nr 42, s. 8.

78 Już w 1890 r. L. Fiszer wydał Katalog czytelni polskiej, francuskiej i angielskiej znajdującej się przy księgarni i składzie nut. W 1909 r. opublikowano Katalog ruskich i niemieckich knig, natomiast K. Fiszer, w 1925 r., wydał Katalog książek polskich wypożyczalni Ludwika Fiszera w Łodzi, a rok później - Katalog wydawnictw Księgarni L. Fiszera w Łodzi. Zob. M. Marczyńska, R. Żmuda, Bibliografia łódzkiej produkcji wydawniczej 1918-1939, Łódź 1986, s. 18.

79 J. Krakowiak, Od Fiszera..., s. 21. 
Dobrze prosperująca firma księgarsko-wydawnicza Fiszerów z końcem lat 20. XX w. zaczęła podupadać. Dość śmiałym, biorąc pod uwagę kwestie finansowe, przedsięwzięciem K. Fiszera było przeniesienie w 1928 r. do nowego lokum dwóch punktów księgarskich założonych wcześniej w Katowicach ${ }^{80}$. W niedługim czasie pojawiły się kłopoty finansowe, potęgowane światowym kryzysem ekonomicznym lat 30. XX w. Unikano wierzycieli i przekładano terminy spłat, o czym świadczyć może korespondencja K. Fiszera do W. Pfeiffera z tego okresu ${ }^{81}$. Sytuacji firmy nie poprawiła sprzedaż rodzinnego domu przy ul. Piotrkowskiej 47, dokonana w 1929 r. Księgarnia w Katowicach ogłosiła upadłość, natomiast łódzką księgarnię, wraz z księgozbiorem, sprzedano Szarlotcie Seipelt we wrześniu 1932 r. $^{82}$

Przez 50 lat swej działalności, jedna z najstarszych firm księgarskich w Łodzi - księgarnia „Ludwika Fiszera” kształtowała rynek wydawniczy i potrzeby czytelnicze wielonarodowościowej społeczności miasta. W latach 1882-1918, dzięki operatywności i staraniom jej pierwszych i kolejnych właścicieli, wydano 400 książek i broszur, nie licząc czasopism i druków ulotnych. Do momentu likwidacji firmy w 1932 r., ukazało się przeszło 700 druków (łącznie ze wznowieniami), wśród których - jak już pisano - podręczniki osiągnęły nakłady do 6 tys. egzemplarzy, a książki dla młodzieży od 2 do 3 tys. ${ }^{83}$

Niezależnie od okresu historycznego i warunków polityczno-ekonomicznych, księgarnia „Ludwika Fiszera” przez pół wieku pełniła ważną rolę społeczną i kulturalną. Działalność wydawnicza ukierunkowana głównie na publikacje podręcznikowe oraz dla dzieci, uczącej się młodzieży i dorosłych, rozwijanie czytelnictwa poprzez udostępnianie książek we własnej wypożyczalni, animacja życia intelektualnego i kulturalnego - obok działalności handlowej - sytuują firmę w gronie instytucji mających znaczący wpływ na rozwój oświaty i szkolnictwa w Łodzi końca XIX i pierwszych trzech dekad XX wieku.

\footnotetext{
80 Por. przypis 22.

81 APŁ, AWP, s. a. 1: Sprawy księgarskie...
}

82 Tamże, k. 11; J. Krakowiak, Od Fiszera..., s. 11; J. Strzałkowski, Drukarnie i księgarnie..., s. 51. Ciekawe są dalsze losy księgarni przy ul. Piotrkowskiej 47, jej historia łączy się bowiem ze współczesnością. Sz. Seipelt prowadziła księgarnię do 1940 r. (1940-1945 - niemiecki zarząd komisaryczny). W latach 1945-1950 księgarnia stała się własnością Wojskowego Instytutu Naukowo-Wydawniczego i pierwszą na terenie miasta placówką księgarską. W latach 1950-1981, po zmianach w strukturze organizacyjnej polskiego księgarstwa, została filią Państwowego Przedsiębiorstwa „Dom Książki”, a jej znakiem firmowym od połowy lat 50. XX w. stał się pegaz (otrzymała nazwę „Księgarnia Pegaz”). Do lat 90. tamtego stulecia księgarnię, z ramienia „Domu Książki”, prowadził Jan Misiowiec. W 1991 r. księgarnia została sprywatyzowana, a jej historia kończy się w sierpniu 2010 r. (kamienica, w której miała siedzibę, została sprzedana). Więcej zob. J. Podolska, Koniec Pegaza. Księgarni, która działała od 1918 roku, http://lodz.gazeta.pl/,13.08.2010 (data dostępu: 30.08.2012).

83 J. Krakowiak, Od Fiszera..., s. 24. 